\title{
STUDENTS' ABILITY IN TRANSFORMING A SENTENCE: DEEP AND SURFACE STRUCTURE
}

\author{
Nina Afrida \\ IAIN Langsa \\ ninaafrida@yahoo.com \\ Khairurrahmi \\ SMP Ulumul Islam, Aceh Utara \\ khairurrabmi@gmail.com
}

\section{ABSTRACT}

The present study aims at exploring students' difficulties in determining deep and surface structure in sentences. The study used quantitative descriptive as a research design. Test and questionnaire were employed as data collection technique. The population of the study is all seventh semester students of English Education Department, since they have studied syntax in the previous semesters. 50 students were sampled in this study. The study reveals that most of students cannot transform deep structure into surface structure. They only can identify the surface structure of simple sentences. The study also shows that English Education Department students find much difficulty in determining the labeling of the words in surface structure, for they cannot classify the class of wordos in surface structure. The study suggests that the ability to differentiate word categories be essential in transforming the surface structure generated through deep structure.

\section{Keyword}

Students' difficulty, syntax, deep structure and surface structure.

\section{INTRODUCTION}

Syntax is micro linguistics which becomes one of the compulsory subjects at English Education Department. Linguistics provides us with a language for describing syntax. Syntax is the study of the rules governing the way words are combined to form sentences in a language. For Chomsky, the goal of the study of syntax is to describe the set of rules, or grammar, that enable us to produce and understand language. Chomsky argues that it is important to distinguish idealized linguistic competence from actual linguistic 
performance. The ability to identify classifications of words becomes essential in understanding this subject.

In the standard theory, the syntactic component generates a deep structure and the surface structure for every sentence. The deep structure is the output of the base rules and the input to the semantic component, while surface structure is what is in your mind or you write and say (Harley, 2014). In other words, deep structure is a structure which is in the mind of the speaker and had a complete meaning, while surface structure is the sentence which is spoken or written. In deep structure, the true meaning of what we want to say is kept on people's mind, for instance when someone wants to convey his/her idea to other people, she/he needs to express it in a sentence so that it can be understood by other people. That is the reason why the students need to learn deep and surface structure to minimize the misunderstanding in understanding the sentence in detail.

At English Education Department of IAIN Langsa, students are required to take syntax in accomplishing their study. Syntax is taken at the fifth semester. In this case, the English Education Department students must learn about the sentence structure and parse it in a sentence. They need to really understand of how to compose a good sentence with a complete meaning in detail. It is very important for them because they will be an English education teacher in the future. In the future, they will teach students how to make well structured sentences. Here, their understanding about syntax will help them to be more competent in their teaching. By studying syntax, they will be able to understand the classification and the orders of words in sentences. They will not be able to teach English to students if they do not know about the English sentence structure well. It is hard to imagine how sentences of the complexity typical in technical writing could be 
understood without utilizing syntactic restriction to select the correct analysis (Ralph Grishman, 1994:11) Because of that, syntax becomes very important for English Education Department students and they have to master this lesson so that they will become a good English teacher.

However, some of the students at seventh semester still find difficulty in identifying word class. Some of them still made mistakes in identifying surface and deep structure in sentences. Therefore, this study attempts to investigate the seventh semester students' ability in determining deep and surface structure toward some sentences and the difficulty faced by the students in distinguishing deep structure from surface structure in sentences.

\section{LITERATURE REVIEW}

Linguistics provides us with a language for describing syntax. Syntax is the study of the rules governing the way words are combined to form sentences in a language. For Chomsky, the goal of the study of syntax is to describe the set of rules, or grammar, that enables us to produce and understand language. Chomsky argues that it is important to distinguish between our idealized linguistic competence, and our actual linguistic performance (Trevor A. Harley, 2014). Our linguistic competence is what is tapped by our intuitions about which are acceptable sentences of our language and which are ungrammatical strings of word.

Linguistics is the study of language itself, the rules that describe it, and our knowledge about the rules of language. A primary goal of linguistics was taken to be providing an analysis of the appropriate categories of description of the unit of language. In modern linguistics, the primary data used by linguists are intuitions about what is and is not an acceptable sentence. Chomsky's work is based on two related ideas. First, the relations between 
language and the brain, and how children acquire language, and second, a technical description of the structure of language.

The way to describe the underlying syntactic structure of sentences is called transformational grammar. It is a method in analyzing sentence based on its structure. Here are the notations used in transformational grammar.

a. Phrase categories (Preposition-phrase, noun phrase)

b. Grammatical categories (parts of speech)

c. Secondary grammatical categories (case: the function of thing in sentence, tense (past, present, future), aspect (possessive, perspective), voice (passive and active), mood (declarative, imperative, interrogative)

d. Functional categories (S, V, O, direct-indirect, $\mathrm{C})$

e. Sub categorization is syntactic feature of word

f. Strict sub categorization: syntactic feature of a word which is related with semantic. For example: red rose

g. Selectional restriction is the restriction on the combination of word due to semantic feature of word. For example: fish loves spoon

In analyzing sentence, one also can use Immediate Constituent (IC) analysis. It is a method in analyzing a sentence by dividing constituents into sub component parts. There are three kinds of IC analysis; they are bracketing system, tree diagram, and Phrase Structure Grammar (PSR) (Robert D. Van Valin JR). These tree kinds of Immediate Constituents has been so far used in transforming the deep structure of the sentences into the surface structure of the sentences. Below are the figures of the pattern for Immediate Constituents 
Figure I

Bracketing system

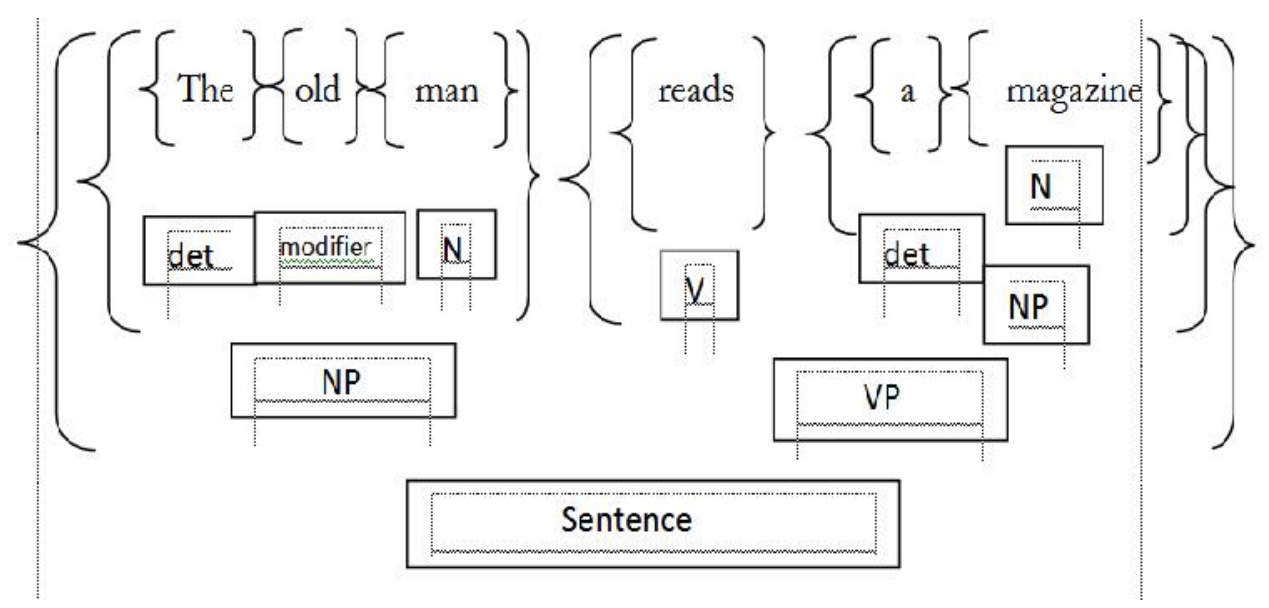

Figure II

Tree diagram

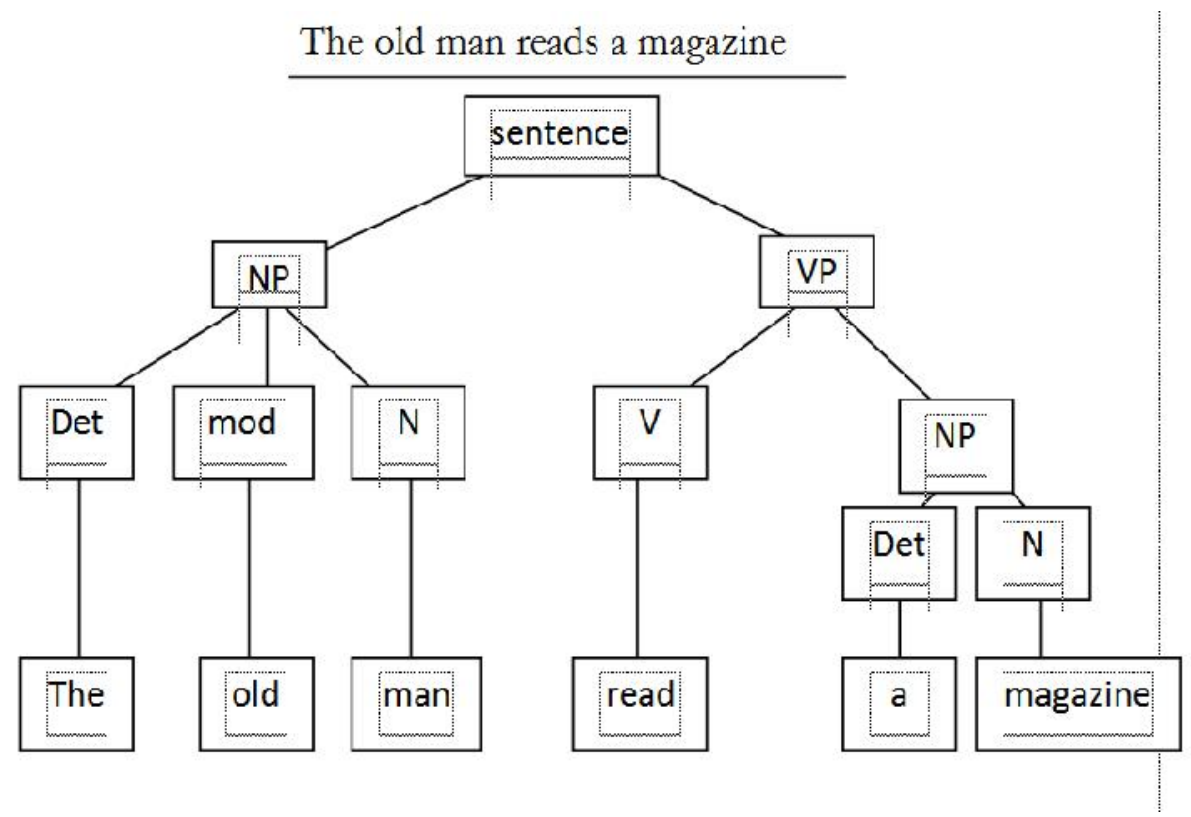




\section{Figure III}

PSR
a. $\mathrm{S}=\mathrm{Np}+\mathrm{Vp}$
b. $\quad \mathrm{Np} 1-\operatorname{Det} 1+\operatorname{Mod}+\mathrm{N} 1$
c. $\mathrm{Vp}=\mathrm{V}+\mathrm{Np} 2$
d. $\mathrm{Np} 2=\operatorname{Det} 2+\mathrm{N} 2$
(c) I)e1 = 'I'ho
f. $\operatorname{Mod}=$ Old
y. N1 - Man
h. V-Rcads
i. $\operatorname{Det} 2=\mathrm{A}$
j. $\quad \mathrm{N} 2=$ Magazinc

Tree diagram is very important in the analysis of syntax, and it is important to be clear about what they mean. Each sentence must contain at least one clause, and each clause must have a subject and every sentence must have a subject. However, not all sentences have an object. Sentences which contains intransitive verb, only have a subject. All sentences are transformed from deep structure into surface structure by generating the process.

In the standard theory, the syntactic component generates a deep structure and surface structure for every sentence. The deep structure is the output of the base rules and the input of the semantic component. Diane D. Bornstein (1984) argues that the surface structure is the output of the transformational rules and the input to the phonological rules.

Deep structure and surface structure are produced by two types of rules. Phrase structure rules generate the sentences that are found in the deep structures. Transformational rules change around the sentences, making 
them into surface structures. Both types of rules are assumed to be part of the individual's linguistic competence.

A transformational grammar assumes that there are two levels of each sentence, a deep structure that represents the meaning, and a surface structure that represents the sound. When a surface structure relates to more than one deep structure, we have a case of ambiguity. In sentence "John is easy to please" and "John is eager to please" have the same surface structure, but their deep structures reveal the different grammatical relations that account for their different meanings.

\section{RESEARCH METHOD}

This research was conducted at IAIN Zawiyah Cot Kala Langsa from August to November 2015. The population of the study is all seventh semester students registered in the academic year 2015-2016. Simple random sampling was used to determine the number of the sample studied (Yatim Riyanto, 2010). 10 students from each class was randomly selected to participate in this study. While the instruments of the study used were test and questionnaire:

Test is an instrument that requires subject to complete a cognitive task by responding to a set of questions. The test distributed to the sample consisted of a battery of questions that measure the ability of the students to identify and label the classification of words in surface structures in the sentences. This study also used an open questionnaire in which the alternatives were not determined by the researcher (Noor, 2011).

The data obtained through test and questionnaire was statistically calculated. The ability of the students in identifying deep structure and surface structure referrs to the following criteria. 


\begin{tabular}{|c|c|}
\hline Scores & Level of competence \\
\hline 90 & Excellent \\
\hline 80 & Very Good \\
\hline 70 & Good \\
\hline 60 & Enough \\
\hline$=>50$ & Failed \\
\hline
\end{tabular}

\section{FINDING AND DISCUSSION}

The test administered investigated the students' ability in transforming the deep structure into surface structure. The following five sentences were distributed to 50 students and they were asked to withdraw the tree diagram to generate their surface structure.
a. The children kicked the tree in the garden
b. The doctor will examine the patients tomorrow
c. Ms. Diana teaches English every morning
d. Students are discussing the difficult task in the classroom now
e. The students threw the ball to the wall hard
f. The man sent a letter last night

Below are the students' scores in doing the surface and deep structure test:

\section{Tabel I}

Students' scores in Deep and Surface Structure

\begin{tabular}{|c|c|c|c|c|}
\hline No. & Student & $\begin{array}{c}\text { Total } \\
\text { correct }\end{array}$ & score & $\begin{array}{c}\text { Level of } \\
\text { Competence }\end{array}$ \\
\hline 1 & Student 1 & 8 & 80 & Very Good \\
\hline
\end{tabular}




\begin{tabular}{|c|c|c|c|c|c|}
\hline 2 & Student & 2 & 9 & 90 & Excellent \\
\hline 3 & Student & 3 & 8 & 30 & Failed \\
\hline 4 & Student & 4 & 8 & 80 & Very Good \\
\hline 5 & Student & 5 & 8 & 50 & Failed \\
\hline 6 & Student & 6 & 5 & 50 & Failed \\
\hline 7 & Student & 7 & 9 & 90 & Excellent \\
\hline 8 & Student & 8 & 8 & 40 & Failed \\
\hline 9 & Student & 9 & 7 & 70 & Good \\
\hline 10 & Student & 10 & 6 & 60 & Enough \\
\hline 11 & Student & 11 & 6 & 60 & Enough \\
\hline 12 & Student & 12 & 8 & 40 & Failed \\
\hline 13 & Student & 13 & 6 & 60 & Enough \\
\hline 14 & Student & 14 & 7 & 30 & Failed \\
\hline 15 & Student & 15 & 8 & 40 & Failed \\
\hline 16 & Student & 16 & 7 & 20 & Failed \\
\hline 17 & Student & 17 & 8 & 50 & Failed \\
\hline 18 & Student & 18 & 6 & 60 & Enough \\
\hline 19 & Student & 19 & 7 & 70 & Good \\
\hline 20 & Student & 20 & 5 & 50 & Failed \\
\hline 21 & Student & 21 & 6 & 60 & Enough \\
\hline 22 & Student & 22 & 7 & 70 & Good \\
\hline 23 & Student & 23 & 5 & 50 & Failed \\
\hline 24 & Student & 24 & 6 & 60 & Enough \\
\hline 25 & Student & 25 & 7 & 70 & Good \\
\hline 26 & Student & 26 & 7 & 70 & Good \\
\hline 27 & Student & 27 & 7 & 40 & Failed \\
\hline 28 & Student & 28 & 5 & 50 & Failed \\
\hline
\end{tabular}




\begin{tabular}{|c|c|c|c|c|c|}
\hline 29 & Student & 29 & 7 & 70 & Good \\
\hline 30 & Student & 30 & 7 & 40 & Failed \\
\hline 31 & Student & 31 & 7 & 50 & Failed \\
\hline 32 & Student & 32 & 5 & 50 & Failed \\
\hline 33 & Student & 33 & 6 & 40 & Failed \\
\hline 34 & Student & 34 & 7 & 50 & Failed \\
\hline 35 & Student & 35 & 7 & 70 & Good \\
\hline 36 & Student & 36 & 7 & 70 & Good \\
\hline 37 & Student & 37 & 6 & 60 & Enough \\
\hline 38 & Student & 38 & 7 & 40 & Failed \\
\hline 39 & Student & 39 & 6 & 60 & Enough \\
\hline 40 & Student & 40 & 7 & 70 & Good \\
\hline 41 & Student & 41 & 8 & 30 & Failed \\
\hline 42 & Student & 42 & 7 & 40 & Failed \\
\hline 43 & Student & 43 & 7 & 20 & Failed \\
\hline 44 & Student & 44 & 6 & 50 & Failed \\
\hline 45 & Student & 45 & 7 & 70 & Good \\
\hline 46 & Student & 46 & 6 & 60 & Enough \\
\hline 47 & Student & 47 & 7 & 40 & Failed \\
\hline 48 & Student & 48 & 6 & 60 & Enough \\
\hline 49 & Student & 49 & 7 & 70 & Good \\
\hline 50 & Student & 50 & 6 & 60 & Enough \\
\hline
\end{tabular}

The table shows that only 2 students or $4 \%$ secure excellent level, 2 students (4\%) obtain Very Good level of performance, 11 students or $22 \%$ fall into Good category, 12 students or 23\% are in Enough level of performance, while 24 students or $47 \%$ fail. The table also indicates that the majority of the 
students dominates the category of Failed (47\%) followed by Enough (23\%), Good (22\%), Very Good (4\%) and Excellent (4\%) respectively. The following is the pie chart denoting the level of the competence, the students fall into.

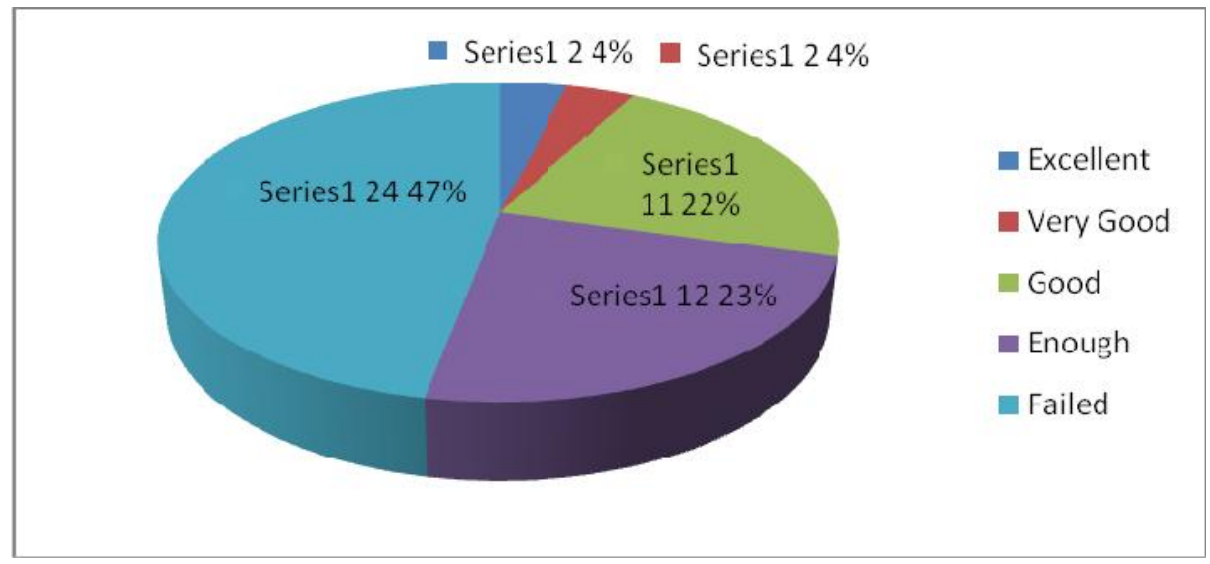

The study reveals that the students always make mistakes in identifying the correct form of a verb, such as the use of the verb 'kick' instead of the past form of the verb 'kicked', the verb 'throw' instead of the verb 'threw', the verb 'discuss' instead of the verb 'discussing', 'wait' instead of 'waiting, 'wake' instead of 'waking'. The other mistakes the students did were related to the students' inability to place the morphemes ' $\mathrm{s}$ ' or 'es' denoting the third person singular in the present form, such as in the words 'teaches and 'washes'.

The students were also found to have faced difficulty in categorizing the class of word under the Noun Phrase (NP). They do not know how to label the words under NP. They very frequently omitted the words when they could not identify the label of the word, such as the omission of the articles before the noun. Unnecessary labeling were also used by the students, such as an additional category of future under the auxiliary verbs and the 
label of adverbial phrase instead of adverb of time under the NP. Similarly, many students were not able to put the determiner in a correct label. They labeled the determiner as NP and the reverse the order of the labels such as the use of 'in' before the word 'discuss'

Since many students find much difficulty in identifying surface structure from deep structure, the study reveals that there are some factors contributing to the poor performance of the students in transforming the deep structure into surface structure through tree diagram.

Majority of the students do not have deep understanding of deep and surface structure. 40 students $(80 \%)$ view that deep and surface structure is difficult to understand. While only 10 students $(20 \%)$ do not articulate their response. The students also say that they cannot label all the words without looking at their note. On the other hand, 30 students $(60 \%)$ say that they do not they understand deep and surface structure. 5 students (10\%) do not provide any response and 15 students (30\%) are not certain in the difference of deep and surface structure in sentences.

The poor performance of the students might be related to the students' attitude and response towards deep and surface structure topic. This study also indicates that 45 students $(90 \%)$ do not like these topics and only 5 students $(10 \%)$ who view that to the topic is interesting. 35 students $(70 \%)$ view syntax is not important in learning the language, while 15 students or 30\% do not know if it is important.

In dealing with the difficulty faced in understanding deep and surface structure, 25 students $(50 \%)$ view that practicing would help students to overcome the problem, 20 students $(40 \%)$ believe that listening more carefully and thoroughly to the lecturer's explanation would be very useful in 
solving the problems faced, while 5 students (10\%) perceive that learning through online materials would be very helpful to cope with this.

\section{CONCLUSION AND SUGGESTION}

The study concludes that the level of competence of the seventh semester students of English Education Department, IAIN Cot Kala Langsa is still poor. It is very obvious that most of all students cannot identify and label the transformation from deep into surface structure in some sentences. The attitude and lack of understanding of the topic are factors contributing to the poor performance of the students in doing the test. A new strategy, method and technique should be introduced to familiarize the students to the topic. Hence the students would show a positive response to the topic.

\section{REFERENCE}

Bisard, Frank et al. Grammar, Meaning and Pragmatics. Amsterdam: Jhon Benjamins B.V.

Grishman, Ralph. (1994).Computional Linguistics. New York: Cambridge University press.

Harley, Trevor A. (2014). The Pdyschology of Language : From Data to Theory. New York: Psychology press.

Kuroda, S.Y. (2013). The (W)Hole Of The Doughnut: Syntax And Its Boundaries. Amsterdam: John Benjamin B.V.

Noor, Juliansyah. (2011). Metodologi Penelitian. Jakarta: Kencana Prenada Media Group.

Ryanto, Yatim. (2010). Metodologi Penelitian Pendidikan. Surabaya: SIC.

Setyadi, Ag Bambang. (2006). Metodologi Penelitian Untuk Pengajaran Bahasa Inggris. Yogyakarta: Graha Ilmu. 
Stazny, Philipp. (2005). Encyclopedia Of Linguistics. New York: Taylor and Fancis Books, Icn.

Sugiyono. (2010). Metode Penelitian Pendidikan Pendekatan Kuantitative, Kualitative, dan $\mathrm{RD}$. Bandung: Alfabeta.

Sujarweni, V. Wiratna and Endrayanto, Poly. (2012). Statistika Untuk Penelitian. Yogyakarta: Graha Ilmu.

STAIN ZCK. (2013). Panduan Akedemik STAIN Zawiyah Cot Kala Langsa. Langsa: STAIN Zawiyah cot kala langsa.

Valin JR, Robert D. Van. (2001). An Introduction To Syntax. New York: Cambridge University Press. 